\title{
Extension of the species Helicobacter bilis to include the reference strains of Helicobacter sp. flexispira taxa 2, 3 and 8 and Finnish canine and feline flexispira strains
}

\author{
M.-L. Hänninen, R. I. Kärenlampi, J. M. K. Koort, T. Mikkonen \\ and K. J. Björkroth

\begin{abstract}
Department of Food and Environmental Hygiene, Faculty of Veterinary Medicine, Helsinki University, PO Box 66, FI-00014 Helsinki, Finland
\end{abstract}

Correspondence

M.-L. Hänninen

marja-liisa.hanninen@helsinki.fi

\begin{abstract}
The evolution and taxonomy of enterohepatic Helicobacter species with flexispira morphology were studied by a polyphasic approach including phenotypic characterization, analysis of $16 \mathrm{~S}$ rRNA and ure $B$ gene sequences and dot-blot DNA-DNA hybridization of whole genomic DNA. In addition, available phylogenetic data on the HSP60 gene were used in the analysis. The study included 14 Finnish canine and feline flexispira strains, the reference strains of Helicobacter sp. flexispira taxa 2, 3 and 8 and Helicobacter bilis ATCC $51630^{\top}$. Phenotypically, all canine and feline strains were similar to $H$. bilis. Analysis of $16 \mathrm{~S}$ rRNA gene sequences of these strains revealed a similarity of 97-99.5\%. Similarity of $u r e B$ nucleotide and amino acid sequences within the studied flexispira group was $97-100 \%$ and $99-100 \%$, respectively, revealing close relatedness. ureB sequences of Helicobacter hepaticus had only $64-66 \%$ similarity to the flexispira group. The similarity to Helicobacter trogontum was $81 \cdot 5-82 \cdot 1 \%$. High levels of DNA-DNA hybridization between the strains were found in dot-blot tests. Polyphasic analysis of the phenotypic and genotypic characteristics of the Finnish flexispira strains and the reference strains of taxa 2, 3 and 8 showed that they differed from other Helicobacter species and are members of the previously described species $H$. bilis. In addition, canine strain F56 differed in all phylogenetic analyses from the $H$. bilis group and probably represents a novel Helicobacter species.
\end{abstract}

\section{INTRODUCTION}

The taxonomy and diversity of the genus Helicobacter has been extended during the last 10 years to contain 23 species with validly published names (http://www.bacterio.cict.fr/h/ helicobacter.html; last updated January 2004). Helicobacter aurati, Helicobacter bilis, Helicobacter canis, Helicobacter cinaedi, Helicobacter cholecystus, Helicobacter fennelliae, Helicobacter hepaticus, Helicobacter marmotae, Helicobacter muridarum, Helicobacter pametensis, Helicobacter pullorum and Helicobacter trogontum colonize the lower intestinal tract of various animal species (Solnick \& Schauer, 2001; Fox et al., 2002). Some of these species seem to be strictly host-adapted, such as $H$. canis in dogs and $H$. pametensis in birds (Solnick \& Schauer, 2001). Certain enterohepatic Helicobacter species, e.g. 'Flexispira rappini' and H. pullorum,

Published online ahead of print on 29 October 2004 as DOI 10.1099/ ijs.0.63245-0.

The GenBank/EMBL/DDBJ accession numbers for the $16 \mathrm{~S}$ rRNA and ure $B$ gene sequences of flexispira strains obtained in this study are AY578094-AY578113. have shown potential for zoonotic transmission (Archer et al., 1988; Romero et al., 1988; Stanley et al., 1994). Moreover, DNA of $H$. bilis, $H$. hepaticus, 'F. rappini', H. pullorum and Helicobacter pylori has been detected by PCR from the bile and gall bladder of human patients with various hepatobiliary diseases (Fox et al., 1998; Ljungh \& Wadström, 2002; Silva et al., 2003). An increased seropositivity for non-gastric Helicobacter species has also been detected in serum of patients with autoimmune liver diseases (Nilsson et al., 2003). The host spectrum of several intestinal Helicobacter species is not fully known, due to limited studies on a large variety of animals. Cultivation of intestinal Helicobacter species requires fresh samples and adequate culture techniques, limiting the knowledge gained on their taxonomy, ecology and epidemiology.

'F. rappini' is a provisional name given by Bryner and colleagues (Bryner, 1987; Bryner et al., 1988) to a group of organisms originally isolated from aborted sheep fetuses (Kirkbride et al., 1986). Flexispiras, which have spindleshaped cells surrounded by periplasmic fibrils and bipolar tufts of sheathed flagella, were later shown to be members 
of the genus Helicobacter (Paster et al., 1991; Dewhirst et al., 2000a). The flexispira group includes the four named species H. bilis (Fox et al., 1995), H. trogontum (Mendes et al., 1996), H. muridarum (Lee et al., 1992) and H. aurati (Patterson et al., 2000), originally isolated from mice, rats, mice and hamsters, respectively, and several unnamed taxa based on 16S rRNA gene sequence analysis (Dewhirst et al., 2000a). Recently, the species $H$. trogontum was extended when a polyphasic approach in studies of their taxonomy was used to include some porcine Helicobacter strains as well as the reference strains of provisional taxa 1, 4 and 5 (Hänninen et al., 2003). H. bilis and taxa 2, 3 and 8 have been shown to produce cytolethal distending toxin but no toxin production was found in $H$. trogontum (Kostia et al., 2003). Dewhirst et al. (2000a) proposed the provisional name Helicobacter sp. flexispira taxa 1 to 8 and 10 for unnamed Helicobacter species with flexispira morphology based on 16S rRNA gene sequences. A group of Helicobacter sp. flexispira without validly published taxonomy has been isolated from pigs (taxon 2), sheep (taxon 3), dogs (taxa 7 and 8) and humans (taxon 8) (Dewhirst et al., 2000a). Bacteria with flexispira morphology have also been isolated from blood of patients with bacteraemia (Tee et al., 1998; Sorlin et al., 1999; Weir et al., 1999) and in faecal samples of patients with diarrhoea, and their DNA has been detected in bile and liver samples in association with various hepatobiliary diseases (Fox et al., 1998; Matsukura et al., 2002).

Analysis of 16S rRNA gene sequences has been one of the most common methods used for studies of phylogeny and taxonomy of bacteria, including Helicobacter species (Vandamme et al., 1996; Dewhirst et al., 2000b; Stackebrandt et al., 2002). However, several examples among Helicobacter indicate that $16 \mathrm{~S}$ rRNA gene sequences are not good markers for species identification of certain Helicobacter species. Helicobacter bizzozeronii and Helicobacter salomonis, for instance, have sequences that can be more than $99 \%$ similar (Jalava et al., 1997). By contrast, the intraspecies diversity within $H$. cinaedi and $H$. trogontum can be $4 \%$, which is higher than the interspecies diversity between some enterohepatic Helicobacter species (Vandamme et al., 2000; Hänninen et al., 2003). The name flexispira is sometimes used for bacteria that do not have spiral morphology or fibrils outside the cell and that have only one flagellum at each end of the cell, based on the high similarity of their $16 \mathrm{~S}$ rRNA gene sequence to a strain of Helicobacter sp. flexispira taxon 8 (Iten et al., 2001).

Here, we report, using a polyphasic approach, that Helicobacter sp. flexispira taxa 2, 3 and 8 , some canine and feline flexispira strains and $H$. bilis constitute a species. In addition, we found that a flexispira strain isolated from a dog differs from $H$. bilis in several genetic characteristics.

\section{METHODS}

Bacterial strains. Bacteria with flexispira morphology were isolated from 14 dogs and cats using either a filtration technique on Brucella blood agar or culture of faecal material on freshly prepared Brucella blood agar medium containing $\left(\mathrm{ml}^{-1}\right) 2 \cdot 5 \mathrm{U}$ polymyxin $\mathrm{B}$, $5 \mu \mathrm{g}$ trimethoprim, $10 \mu \mathrm{g}$ vancomycin and $2 \mu \mathrm{g}$ amphotericin $\mathrm{B}$ (Hänninen et al., 2003). The medium was incubated at $37^{\circ} \mathrm{C}$ for up to 7 days in a microaerobic atmosphere containing $5 \%$ oxygen, $10 \% \mathrm{CO}_{2}$ and $3 \% \mathrm{H}_{2}$ and observed for spreading growth. Bacteria with flexispira morphology were identified using light microscopy and certain cultures (F56, F57, KI900, KO220, KI520, KI311 and $\mathrm{KO} 214$ ) were later confirmed by transmission electron microscopy to have typical flexispira morphology (Hänninen et al., 2003). During earlier studies, the strains were tested several times for catalase, oxidase and urease production (Hänninen et al., 1996, 2003). In addition, the strains were characterized for the following features:

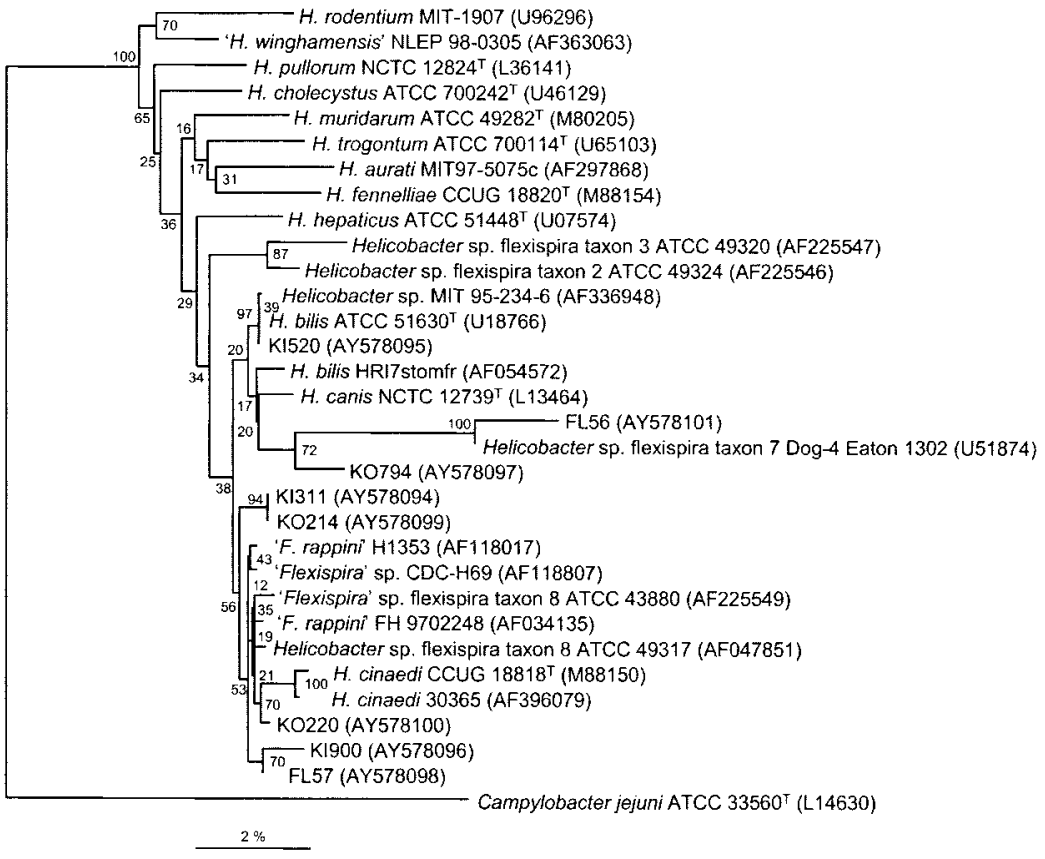

Fig. 1. Phylogenetic tree of representative enterohepatic Helicobacter species based on $16 \mathrm{~S}$ rRNA gene sequences ( $>1400$ nucleotides). The tree was constructed using a neighbour-joining method rooted with Campylobacter jejuni. GenBank accession numbers are given in parentheses. Numbers at each node represent percentages of bootstrap support calculated from 1000 probable trees. Bar, 2\% sequence divergence. 
nitrate reduction, urease, $\gamma$-glutamyl transferase and esterase using API CAMPY (bioMérieux), growth at 25 and $42{ }^{\circ} \mathrm{C}$ and on $1 \%$ glycine and sensitivity to nalidixic acid and cephalothin (Hänninen et al., 1996, 2003).

Sequencing. For sequencing studies, DNA was isolated as described elsewhere (Hänninen et al., 1996, 2003; Mikkonen et al., 2004). The nearly complete (at least 1400 bases sequenced) $16 \mathrm{~S}$ rRNA genes of eight Finnish canine and feline flexispira strains were amplified by PCR with universal primer pair F19-38 (5'-CTGGCTCAGGAYGAACGCTG-3') and R1541-1522 (5'-AAGGAGGTGATCCAGCCGCA-3'). Sequencing of the purified (QIAquick PCR purification kit; Qiagen) PCR products was performed by Sanger's dideoxynucleotide chain-termination method using primers F19-38, R1541-1522, F908-926 (5'-AACTCAAAGGAATTGACGG-3') and R536-519 (5'-GTATTACCGCGGCTGCTG-3'). Samples were run in a Global $\mathrm{IR}^{2}$ sequencing device with e-Seq 1.1 software (LiCor) according to the manufacturer's instructions. Overlapping complementary sequences were joined using the Align IR 1.2 program (LiCor). The consensus sequences of strains belonging to Helicobacter species and Campylobacter jejuni (outgroup) [retrieved from/ deposited in GenBank (http://www.ncbi.nlm.nih.gov) using BLASTN 2.2.6 (Altschul et al., 2001)] were aligned and a phylogenetic tree was constructed from the global alignment by the neighbour-joining algorithm using the BioNumerics 3.0 software package (Applied Maths). Bootstrap probability values were calculated from 1000 resampled trees. Fig. 1 shows the distance matrix tree based on $16 \mathrm{~S}$ rRNA gene sequences and the accession numbers of the 16S rRNA gene sequences used/deposited. The specificity of the primers designed for identification of $H$. bilis based on 16S rRNA gene amplification was tested by the method of Fox et al. (1995).

Partial sequences of the ureB gene of 12 Helicobacter sp. flexispira strains (Table 1) were produced by automated cycle sequencing with Big Dye terminators (ABI 377XL; PE Applied Biosystems). The sequenced area (519 bp) corresponded to positions 139-658 of the partial 732 bp ureB gene sequence of Helicobacter sp. flexispira ATCC 49315. The primers (ureBFF, 5'-GAGATGGTATGGCGCAATCT-3'; ureBFR 1, 5'-CCCAATCTTCATGCACCTTT-3') amplified a fragment of the expected size from all Helicobacter sp. flexispira strains, except $H$. trogontum. Using another reverse primer (5'-TCAATGCCACCAGCAGTAAC-3'), a 247 bp fragment was also amplified from $H$. trogontum. Additional sequences were available from public databases (Fig. 2). After pairwise and multiple alignments, a phylogenetic tree was constructed by the neighbour-joining method using the JukesCantor coefficient (Fig. 2). The topology of the tree was evaluated by 1000 trials of bootstrap analysis. The $u r e B$ sequences were translated to the corresponding protein sequences with the TRANSEQ program (EMBOSS). The resulting protein sequences were aligned and the neighbour-joining tree was calculated with CLUSTAL W. The phylogenetic tree based on the protein sequences was drawn by the TREEVIEW program 1.6.6 (http://taxonomy.zoology.gla.ac.uk/rod/rod.html).

DNA-DNA hybridization. Dot-blot hybridization of whole genomic DNA was performed for the reference strains of taxa 2, 3 and 8, H. bilis ATCC $50160^{\mathrm{T}}$, H. trogontum ATCC $700114^{\mathrm{T}}$, H. canis NCTC $12739^{\mathrm{T}}$ and $H$. cinaedi CCUG $18818^{\mathrm{T}}$ as well as for 14 canine and feline flexispira strains (Table 1) by the technique employed in our previous studies (Hänninen et al., 1996; Jalava et al., 1997, 2001). The concentrations of DNA used were 50,5 and $0 \cdot 5 \mathrm{ng}$. The strains used as probes were reference strains of taxa 2 (ATCC 49314), 3 (ATCC 49320) and 8 (CCUG 23435) (Table 1), H. bilis ATCC $50160^{\mathrm{T}}, H$. trogontum ATCC $700114^{\mathrm{T}}$ and strains FL56 and FL57. The probes were labelled with digoxigenin with a DNA labelling and detection kit (Roche). Hybridization and all washings were performed at $58^{\circ} \mathrm{C}$. The intensity of hybridization was assessed by
Table 1. Helicobacter strains used in the study

\begin{tabular}{|c|c|}
\hline Strain & Source \\
\hline Helicobacter bilis ATCC $51630^{\mathrm{T}}$ & Mouse faeces \\
\hline \multicolumn{2}{|l|}{ Helicobacter sp. flexispira } \\
\hline FL56 & Canine faeces \\
\hline KO214 & Canine faeces \\
\hline KO220 & Canine faeces \\
\hline KO534B & Canine faeces \\
\hline KO114 & Canine faeces \\
\hline KO115 & Canine faeces \\
\hline KO794 & Canine faeces \\
\hline FL57 & Canine faeces \\
\hline FL76 & Canine faeces \\
\hline KI900 & Feline faeces \\
\hline KI311 & Feline faeces \\
\hline KI520 & Feline faeces \\
\hline KI901 & Feline faeces \\
\hline KI902 & Feline faeces \\
\hline Helicobacter canis NCTC $12739^{\mathrm{T}}$ & Canine faeces \\
\hline Helicobacter cholecystus CCUG $38167^{\mathrm{T}}$ & $\begin{array}{l}\text { Syrian hamster gall } \\
\text { bladder }\end{array}$ \\
\hline Helicobacter cinaedi CCUG $18818^{\mathrm{T}}$ & Human faeces \\
\hline Helicobacter hepaticus CCUG $33637^{\mathrm{T}}$ & Mouse liver \\
\hline Helicobacter muridarum CCUG $29262^{\mathrm{T}}$ & Rat ileum \\
\hline Helicobacter mustelae CCUG $25715^{\mathrm{T}}$ & Ferret gastric mucosa \\
\hline Helicobacter pametensis CCUG 29253 & Tern faeces \\
\hline Helicobacter pullorum NCTC $12826^{\mathrm{T}}$ & Human faeces \\
\hline Helicobacter trogontum ATCC $700114^{\mathrm{T}}$ & Rat \\
\hline $\begin{array}{l}\text { Helicobacter sp., taxon } 286-2279 \\
(=\text { ATCC } 49314)\end{array}$ & Sheep \\
\hline $\begin{array}{l}\text { Helicobacter sp., taxon } 388-2491 \\
(=\text { ATCC } 49320)\end{array}$ & $\begin{array}{l}\text { Pig stomach; aborted } \\
\text { fetus }\end{array}$ \\
\hline $\begin{array}{l}\text { Helicobacter sp., taxon } 8 \text { CCUG } 38944 \\
(=\text { ATCC } 43880)\end{array}$ & Human stool \\
\hline $\begin{array}{l}\text { Helicobacter sp., taxon } 8 \text { CCUG } 23435 \\
(=\text { ATCC } 43879)\end{array}$ & Human stool \\
\hline
\end{tabular}

comparing the intensities of the colour that developed as described previously (Hänninen et al., 1996; Jalava et al., 1997, 2001).

\section{RESULTS AND DISCUSSION}

\section{Morphology}

Light and electron microscopy characterization of the strains showed that they all had cigar-like morphology with external fibrils outside the cell and tufts of sheathed flagella at both ends of the cell, findings typical of organisms (Weir et al., 1999; Sorlin et al., 1999; Jalava et al., 1998; Hänninen et al., 2003) given the provisional name 'flexispira' by Bryner et al. (1987).

\section{Phenotypic characteristics}

The strains were all urease-positive, negative in nitrate reduction, had esterase and $\gamma$-glutamyl transferase activity 


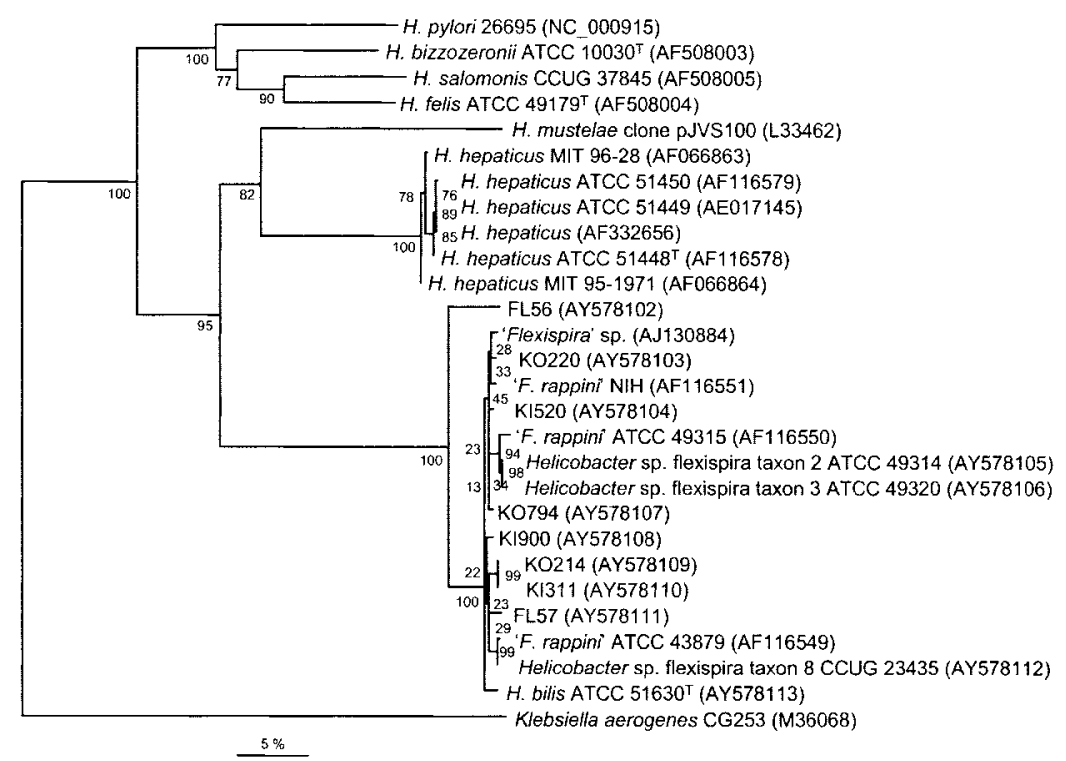

Fig. 2. Phylogenetic tree of representative enterohepatic and gastric Helicobacter species based on partial ure $B$ gene sequences (518 nucleotides). The tree was constructed using a neighbour-joining method rooted with Klebsiella aerogenes. GenBank accession numbers are given in parentheses. Numbers at each node represent percentages of bootstrap support calculated from 1000 probable trees. Bar, $5 \%$ sequence divergence. and grew at $42{ }^{\circ} \mathrm{C}$ but not at $25^{\circ} \mathrm{C}$ and did not grow in $1 \%$ glycine (Table 2). In catalase tests, repeated several times, $10 / 14$ isolates were catalase-negative. In the taxonomic description of the species $H$. bilis, the type strain ATCC $51630^{\mathrm{T}}$ and all other isolates were described as reducing nitrate to nitrite (Fox et al., 1995). In our studies, the type strain ATCC $51630^{\mathrm{T}}$ did not reduce nitrate, even after several separate experiments. Whether the type strain had lost its nitrate reduction capacity during subculture is unknown. Earlier studies have shown that canine flexispiras can be either catalase-negative or catalase-positive (Dewhirst et al., 2000a). These results were confirmed here.

\section{Phylogeny based on the 16S rRNA gene}

Sequences of $H$. bilis ATCC $51630^{\mathrm{T}}$, Helicobacter sp. flexispira taxa 2, 3 and 8 reference strains and Finnish canine and feline flexispira strains and sequences of flexispira strains deposited in GenBank under the names $H$. bilis (HR17 and MIT 93-4659) and ' $F$. rappini'

Table 2. Characteristics of selected non-gastric Helicobacter species

Taxa: 1, H. bilis, 14 Finnish strains; 2, H. bilis ATCC $53630^{\mathrm{T}}$; 3, Helicobacter sp. flexispira, taxon 8; 4, Helicobacter sp. flexispira, taxon 2; 5, Helicobacter sp. flexispira, taxon 3; 6, Helicobacter sp. flexispira, taxon 7; 7, H. aurati; 8, H. trogontum; 9, H. pullorum; 10, H. muridarum; 11, H. hepaticus; 12, H. cinaedi; 13, H. canis; 14, Helicobacter sp. flexispira, taxon 10; 15, H. rodentium. Data were obtained from Dewhirst et al. (2000a), Fox et al. (1995), Hänninen et al. (2003), Mendes et al. (1996), Patterson et al. (2000), Saunders et al. (1999), Shen et al. (1997) and Robertson et al. (2001). ND, Not determined.

\begin{tabular}{|c|c|c|c|c|c|c|c|c|c|c|c|c|c|c|c|}
\hline Characteristic & 1 & 2 & 3 & 4 & 5 & 6 & 7 & 8 & 9 & 10 & 11 & 12 & 13 & 14 & 15 \\
\hline Catalase production & $-(10 / 14)$ & + & $+1-$ & + & + & - & + & + & + & + & + & + & + & + & + \\
\hline Nitrate reduction & $-(14 / 14)$ & - & - & - & - & - & - & - & + & - & + & + & - & - & + \\
\hline Urease & $+(14 / 14)$ & + & + & + & + & + & + & + & - & + & + & - & - & - & - \\
\hline$\gamma$-Glutamyl transferase & $+(14 / 14)$ & + & + & + & + & + & + & + & + & + & - & - & + & - & - \\
\hline Tolerance of glycine, $1 \%$ & $-(14 / 14)$ & + & - & - & - & - & - & ND & - & - & + & + & - & + & + \\
\hline Growth at $42^{\circ} \mathrm{C}$ & $+(12 / 14)$ & + & + & + & + & $+1-$ & + & + & + & - & - & - & + & + & + \\
\hline \multicolumn{16}{|l|}{ Susceptibility to:* } \\
\hline Nalidixic acid $\left(30 \mathrm{ml} \mathrm{l}^{-1}\right)$ & $\mathrm{R}(14 / 14)$ & $\mathrm{R}$ & $\mathrm{R}$ & $\mathrm{R}$ & $\mathrm{R}$ & $\mathrm{R}$ & S & $\mathrm{R}$ & $\mathrm{R}$ & $\mathrm{R}$ & $\mathrm{R}$ & S & S & $\mathrm{R}$ & $\mathrm{R}$ \\
\hline Cephalothin $\left(32 \mathrm{mg} \mathrm{l}^{-1}\right)$ & $\mathrm{R}(14 / 14)$ & $\mathrm{R}$ & $\mathrm{R}$ & $\mathrm{R}$ & $\mathrm{R}$ & $\mathrm{R}$ & $\mathrm{R}$ & $\mathrm{R}$ & s & $\mathrm{R}$ & $\mathrm{R}$ & I & I & $\mathrm{R}$ & $\mathrm{R}$ \\
\hline Periplasmic fibrils & + & + & + & + & + & + & - & + & - & + & - & - & - & + & - \\
\hline Number of flagella & $10-14$ & $3-14$ & $3-14$ & $\mathrm{ND}$ & $\mathrm{ND}$ & ND & $7-10$ & $6-14$ & 1 & $10-14$ & 2 & $1-2$ & 2 & $6-12$ & 2 \\
\hline Distribution of flagella $\dagger$ & $\mathrm{BP}$ & BP & BP & BP & $\mathrm{BP}$ & BP & $\mathrm{BP}$ & BP & MP & BP & $\mathrm{BP}$ & BP & $\mathrm{BP}$ & BP & $\mathrm{BP}$ \\
\hline
\end{tabular}

${ }^{\star} \mathrm{R}$, Resistant; S, susceptible; I, intermediate.

$\dagger \mathrm{BP}$, Bipolar; MP, monopolar. 
(AF034135, AF118017, AF225550, AF336948) were widely dispersed into a cluster, which also included some other enterohepatic Helicobacter species (H. canis NCTC $12739^{\mathrm{T}}$, H. cinaedi CCUG $18818^{\mathrm{T}}$ and ATCC 30365 and H. hepaticus ATCC $\left.51448^{\mathrm{T}}\right)$. H. trogontum was in the same cluster as $H$. muridarum, $H$. aurati and $H$. fennelliae. The bootstrap values supporting the topology of the branching of enterohepatic species were usually low. These results show trends similar to those of several previous studies (Sorlin et al., 1999; Dewhirst et al., 2000a; Vandamme et al., 2000; Hänninen et al., 2003), indicating extensive diversity within enterohepatic Helicobacter species and revealing that the phylogeny of the 16S rRNA gene is inconsistent with the cellular phylogeny and taxonomy of these enterohepatic Helicobacter species. Finnish canine and feline flexispira strains had similarity of $94 \cdot 8-96 \cdot 8 \%$ to $H$. trogontum, $98-100 \%$ to $H$. bilis ATCC $51630^{\mathrm{T}}, 97 \%$ to the reference strains of taxa 2 and 3 and $97-99 \cdot 5 \%$ to taxon 8 . Taxa 2 and 3 were in their own branch, although the bootstrap value supporting their position was low (Fig. 1). The sequence of strain FL56 had only $91 \%$ similarity to taxon 8, H. bilis ATCC $51630^{\mathrm{T}}$ and Finnish canine and feline strains. It had the highest similarity to the taxon 7 reference strain $(98 \cdot 5 \%)$. H. aurati had $95-96 \%$ similarity to the other flexispira strains. The incoherence of the evolution of the 16S rRNA gene with that of enterohepatic Helicobacter species studied by a polyphasic taxonomic approach could be explained by frequent genetic exchanges between enterohepatic species in this genomic region. Several enterohepatic Helicobacter species may simultaneously colonize the intestines of animal hosts, e.g. cats, dogs, mice and rats (Solnick \& Schauer, 2001), enabling genetic recombination between different Helicobacter species. We also tested the specificity of the $H$. bilis $16 \mathrm{~S}$ rRNA gene primers (Fox et al., 1995) and found that they produced fragments from $H$. trogontum ATCC $700114^{\mathrm{T}}$, H. bilis ATCC $51630^{\mathrm{T}}$, H. cinaedi CCUG $18818^{\mathrm{T}}$, the taxon 2 reference strain and five of the Finnish canine flexispira strains examined. These studies revealed that the primers were not specific to $H$. bilis but amplified fragments from other related enterohepatic Helicobacter species as well. These results are concordant with the observation of rather high interspecies $16 \mathrm{~S}$ rRNA gene similarity. High intraspecies diversity of the $16 \mathrm{~S}$ rRNA gene sequence (Vandamme et al., 2000; Hänninen et al., 2003) also suggests that design of a species-specific PCR test for identification of related enterohepatic Helicobacter species will be a difficult task.

\section{Insertion sequences in the 16S rRNA gene}

Insertion sequences have been demonstrated to be rather common in both the $16 \mathrm{~S}$ and $23 \mathrm{~S}$ rRNA genes in Helicobacter species (Hurtado et al., 1997). They seem to be identical or highly similar within a Helicobacter species and interspecies similarities also exist (Hurtado et al., 1997). The insert usually starts in the same region. In our studies, an identical or highly similar (98-100\% similarity) $187 \mathrm{bp}$ insertion sequence, starting at position 220 , was detected in
11 of the flexispira sequences (Fig. 1). Insertion sequences were lacking in six sequences, including the reference strain of taxon 8, ATCC 43880 (Table 1). Insertion sequences of strain FL56 and the taxon 7 reference strain were highly similar and differed from other studied intervening sequences. Previous studies have shown that bacteria with flexispira morphology possess intervening sequences (Dewhirst et al., 2000a). The high similarity of the intervening sequences of $H$. bilis, taxa 2, 3 and 8 and some Finnish canine and feline flexispira strains suggests that these bacteria are also taxonomically highly related, as has been shown to be the case for other Helicobacter species (Linton et al., 1994; Fox et al., 1995). A PCR amplification test specific for intervening sequences can be used as a diagnostic tool to identify those $H$. bilis strains that have an intervening sequence in their 16S rRNA gene, as earlier proposed by Fox et al. (1995).

\section{Phylogeny based on ure $B$ sequences}

ureB has been shown in some previous studies to be suitable for studying the phylogeny and evolution of gastric Helicobacter species (Gueneau \& Loiseaux-De Goër, 2002). Evaluation of the suitability of the ureB gene for the taxonomy of enterohepatic Helicobacter species has been limited by the small number of sequences available. ureB sequence analysis could not, in any case, be used for the whole genus because several urease-negative enterohepatic species exist (Table 2; Solnick \& Schauer, 2001). As expected, the fragment was amplified from the reference strains of taxa 2, 3 and 8 (CCUG 223435). In addition, the same product was amplified from $H$. bilis ATCC $53160^{\mathrm{T}}$ and from all eight Finnish canine and feline strains studied.

The $479 \mathrm{bp}$ ureB sequences were used for phylogenetic analysis and a tree was constructed (Fig. 2). The sequences of $H$. bilis, taxa 2, 3 and 8 reference strains, Finnish canine and feline flexispira strains and the four flexispira sequences from GenBank [' $F$. rappini' ATCC 43879 (AF116549), 'F. rappini' ATCC 49315 (AF1165509), ' $F$. rappini NIH (AF116551) and 'Flexispira' sp. (AJ130884)] clustered tightly together, having $97-100 \%$ similarity. The sequence of $H$. bilis ATCC $51630^{\mathrm{T}}$ was $97-98 \cdot 7 \%$ similar to the flexispira sequences listed above. The flexispira group mentioned above had similarity of $64 \cdot 4-65 \cdot 8 \%$ to $H$. hepaticus ATCC $51448^{\mathrm{T}}$. These results indicate a close genetic relationship between the studied bacteria with flexispira morphology as well as their clear separation from the studied urease-positive enterohepatic Helicobacter species. The only exception was the sequence of strain FL56, which had a similarity of only $91 \cdot 4-93 \cdot 5 \%$ to other flexispira strains. In the phylogenetic tree, strain FL56 was also distinguished from the other flexispira strains, having a high bootstrap value of 100 (Fig. 2). H. hepaticus was represented by six sequences (five from GenBank and a sequence from our study) and they formed their own cluster in the tree. The similarity of the six $H$. hepaticus sequences varied from $99 \cdot 2$ to $99 \cdot 4 \%$, indicating a higher intraspecies similarity than that found for the flexispira 
group. Helicobacter mustelae clustered with the enterohepatic branch and not with the gastric Helicobacter species (Fig. 2), even though it is a gastric-area-colonizing species (Fox et al., 1990). The type strains of the gastric species $H$. pylori, Helicobacter felis, $H$. bizzozeronii and $H$. salomonis formed a gastric branch. Other studies concentrating more on the analysis of ureB gene phylogeny of gastric Helicobacter species have also shown that gastric and enterohepatic species are located in separate clusters (Gueneau \& Loiseaux-De Goër, 2002). Comparison of the respective amino acid sequences indicated $98-100 \%$ similarity for $H$. bilis, Helicobacter sp. flexispira taxa 2, 3 and 8 strains, seven Finnish canine and feline flexispira strains and the four 'F. rappini' sequences from GenBank. FL56 had a similarity of $96-97 \%$ to other strains. Our results suggest that, based on the high similarity of their ureB sequences, $H$. bilis, taxa 2,3 and 8 strains and canine and feline flexispira strains are members of the same species. The lower similarity of FL56 to other flexispira strains suggests that this strain might belong to another species.

Comparison of the sequences of $H$. trogontum with sequences of other flexispira strains was not possible because the primers used failed to amplify its ureB sequence. We therefore performed a limited study on seven strains by developing primers that amplified both canine and feline flexispiras (KO220, FL57, KI311), H. bilis ATCC $51630^{\mathrm{T}}$, taxa 2 and 8 reference strains and $H$. trogontum. Sequencing and analysing this $247 \mathrm{bp}$ fragment revealed that $H$. trogontum ATCC $700411^{\mathrm{T}}$ had only $81 \cdot 5-82 \cdot 1 \%$ similarity to $H$. bilis and other strains studied, suggesting that the phylogeny of this fragment of ureB was concordant with speciation. The sequence similarity within the other flexispira strains was high, from $96 \cdot 5$ to $99 \cdot 5 \%$. In conclusion, these studies showed that ureB sequence analysis can differentiate $H$. trogontum from other flexispiras, including $H$. bilis. PCR with primers ureBFF and ureBR1 can be used for specific amplification of $H$. bilis DNA.

\section{Whole genome DNA-DNA hybridization}

Dot-blot hybridization using three concentrations of genomic DNA revealed a high level of hybridization between H. bilis ATCC $51630^{\mathrm{T}}$, taxa 2, 3 and 8 reference strains and 14 canine and feline flexispira strains. This indicates high whole genomic DNA similarity (results not shown) and suggests that all of these strains are members of a single species, i.e. $H$. bilis. Because $16 \mathrm{~S}$ rRNA gene sequences of $H$. canis and $H$. cinaedi can show high similarity to $H$. bilis and other flexispiras (Fig. 1), DNAs of $H$. canis and $H$. cinaedi were hybridized with probe DNAs as well. The probes hybridized only weakly with the DNAs of $H$. canis and $H$. cinaedi, indicating only low relatedness and revealing that the flexispira group is not part of either $\mathrm{H}$. canis or H. cinaedi. Whole genomic DNA-DNA hybridization has been one of the key taxonomic markers in the delineation of a bacterial species (Stackebrandt et al., 2002). DNADNA hybridization studies have not been performed extensively for Helicobacter species. In our previous studies, we used the present dot-blot technique, which requires less than 100 ng DNA, to describe two novel Helicobacter species, H. bizzozeronii (Hänninen et al., 1996; Jalava et al. 2001) and H. salomonis (Jalava et al., 1997), as well as to describe the extension of $H$. trogontum to include reference strains ATCC 43968, ATCC 43966 and ATCC 49310 (Hänninen et al., 2003).

\section{Phylogeny of HSP60}

Using approximately $600 \mathrm{bp}$ sequences of the HSP60 gene as a phylogenetic marker, we have earlier shown that evolution of the HSP60 gene tends to correspond much better to the taxonomy of the genus Helicobacter than does the 16S rRNA gene (Mikkonen et al., 2004). The study also included $H$. bilis ATCC $51630^{\mathrm{T}}$, taxa 2, 3 and 8 reference strains, some of the canine and feline flexispira strains included in the present study (KO214, KO534B, KO220 and FL56), $H$. cinaedi and $H$. canis, as well as several $H$. trogontum strains. Analysis of HSP60 sequences showed that $H$. bilis, the taxon 8 reference strain and Finnish flexispira strains were in the same branch of the phylogenetic tree and had highly similar sequences, supporting the results of the present study. The sequences of taxa 2 and 3 strains had $88 \cdot 9,96$ and $95 \cdot 4 \%$ similarity to $H$. trogontum, $H$. bilis and the taxon 8 reference strain, respectively. However, the respective amino acid sequences of taxa 2 and 3 differed from the other flexispiras by only one amino acid, indicating close interrelatedness. Strain FL56 had only $90 \cdot 3-91 \cdot 2 \%$ sequence similarity to the H. bilis cluster (Mikkonen et al., 2004), supporting the results of $16 \mathrm{~S}$ rRNA and ureB gene analysis. $H$. canis and $H$. cinaedi clustered with other enterohepatic species and were separated from $H$. bilis and $H$. trogontum.

\section{Conclusions}

Some confusion exists in the taxonomy and naming of organisms with flexispira morphology. $H$. trogontum is a named species associated with rat, sheep and pig, and Kirkbride et al. (1986) and Bryner et al. (1987) have shown that this species is strongly associated with ovine abortions. Our present and previous studies have revealed that a group of flexispira strains isolated from faecal samples of humans, dogs, cats and sheep as well as from the porcine stomach had highly similar phenotypic and genotypic characteristics based on their 16S rRNA, ureB, $c d t B$ and HSP60 gene sequences, had high whole genomic relatedness in DNA-DNA hybridizations and differed from other named Helicobacter species. These facts lead us to conclude that reference strains of taxa 2, 3 and 8 and Finnish canine and feline flexispira strains constitute a single species, $H$. bilis. The methods in our studies fulfil the minimum requirements presented by Dewhirst et al. (2000b) for description of a novel Helicobacter species, as well as the later recommendations of the ad hoc committee for the revaluation of the definition of the bacterial species (Stackebrandt et al., 2002). Strain FL56 had different characteristics from other flexispiras and its position 
requires further studies. Bacteria resembling $H$. bilis have been isolated from blood cultures of human patients in association of bacteraemia (Tee et al., 1998; Sorlin et al., 1999; Weir et al., 1999), and similar DNA has been detected in bile and tissue samples of patients with various hepatobiliary diseases (Fox et al., 1998; Matsukura et al., 2002). These studies suggest that the clinical significance of $H$. bilis in gastrointestinal diseases should be further evaluated using adequate diagnostic methods. Based on its wide spectrum of hosts, $H$. bilis has a capacity for zoonotic transmission. Some case studies have shown potential transmission from dogs to humans (Romero et al., 1988). Our results provide diagnostic tools for further studies on the role of $H$. bilis in various diseases of animals and humans and confirm the power of the polyphasic approach in the taxonomy of species with a complex evolutionary background. More strains are required for studies on the taxonomy of strains FL56 and Helicobacter sp. taxon 7.

\section{ACKNOWLEDGEMENTS}

The financial support of the Research Funds of the University of Helsinki and the Academy of Finland are acknowledged.

\section{REFERENCES}

Altschul, S. F., Bundschuh, R., Olsen, R. \& Hwa, T. (2001). The estimation of statistical parameters for local alignment score distributions. Nucleic Acids Res 29, 351-361.

Archer, J. R., Romero, S., Ritchie, A. E., Hamacher, M. E., Steiner, B. M., Bryner, J. H. \& Schell, R. F. (1988). Characterization of an unclassified microaerophilic bacterium associated with gastroenteritis. J Clin Microbiol 26, 101-105.

Bryner, J. H. (1988). Flexispira rappini, gen. nov., sp. nov. A motile, urease-producing rod similar to Campylobacter pyloridis. In Campylobacter IV. Proceedings of the Fourth International Workshop on Campylobacter Infections, pp. 440-442. Edited by B. Kajser \& E. Falsen. Sweden: Göterna Kungälv.

Bryner, J. H., Richie, A. E., Pollet, L., Kirkbride, C. A. \& Collins, J. E. (1987). Experimental infection and abortion of pregnant guinea pigs with a unique spirillum-like bacterium isolated from aborted ovine fetuses. Am J Vet Res 48, 91-95.

Dewhirst, F. E., Fox, J. G., Mendes, E. N., Paster, B. J., Gates, C. E., Kirkbride, C. A. \& Eaton, K. A. (2000a). 'Flexispira rappini' strains represent at least 10 Helicobacter taxa. Int J Syst Evol Microbiol 50, 1781-1787.

Dewhirst, F. E., Fox, J. G. \& On, S. L. W. (2000b). Recommended minimal standards for describing new species of the genus Helicobacter. Int J Syst Evol Microbiol 50, 2231-2237.

Fox, J. G., Correa, P., Taylor, N. S., Lee, A., Otto, G., Murphy, J. C. \& Rose, R. (1990). Helicobacter mustelae-associated gastritis in ferrets. An animal model of Helicobacter pylori gastritis in humans. Gastroenterology 99, 352-361.

Fox, J. G., Yan, L. L., Dewhirst, F. E., Paster, B. J., Shames, B., Murphy, J. C., Hayward, A., Belcher, J. C. \& Mendes, E. N. (1995). Helicobacter bilis sp. nov., a novel Helicobacter species isolated from bile, livers, and intestines of aged, inbred mice. J Clin Microbiol 33, 445-454.

Fox, J. G., Dewhirst, F., Shen, Z. \& 8 other authors (1998). Hepatic Helicobacter species identified in bile and gallbladder tissue from Chileans with chronic cholecystitis. Gastroenterology 114, 755-763.

Fox, J. G., Shen, Z., Feng, Y., Dangler, C. A., Dewhirst, F. E., Paster, B. J. \& Cullen, C. M. (2002). Helicobacter marmotae sp. nov. isolated from livers of woodchucks and intestines of cats. J Clin Microbiol 40, 2513-2519.

Gueneau, P. \& Loiseaux-De Goër, S. (2002). Helicobacter: molecular phylogeny and the origin of gastric colonization in the genus. Infect Genet Evol 1, 215-223.

Hänninen, M. L., Happonen, I., Saari, S. \& Jalava, K. (1996). Culture and characteristics of Helicobacter bizzozeronii, a new canine gastric Helicobacter sp. Int J Syst Bacteriol 46, 160-166.

Hänninen, M. L., Utriainen, M., Happonen, I. \& Dewhirst, F. E. (2003). Helicobacter sp. flexispira $16 \mathrm{~S}$ rDNA taxa 1,4 and 5 and Finnish porcine Helicobacter isolates are members of the species Helicobacter trogontum (taxon 6). Int J Syst Evol Microbiol 53, 425-433.

Hurtado, A., Clewley, J. P., Linton, D., Owen, R. J. \& Stanley, J. (1997). Sequence similarities between large subunit ribosomal RNA gene intervening sequences from different Helicobacter species. Gene 194, 69-75.

Iten, A., Graf, S., Egger, M., Täuber, M. \& Graf, J. (2001). Helicobacter sp. flexispira bacteremia in an immunocompetent young adult. J Clin Microbiol 39, 1716-1720.

Jalava, K., Kaartinen, M., Utriainen, M., Happonen, I. \& Hänninen, M. L. (1997). Helicobacter salomonis sp. nov., a canine gastric Helicobacter sp. related to Helicobacter felis and Helicobacter bizzozeronii. Int J Syst Bacteriol 47, 975-982.

Jalava, K., On, S. L. W., Vandamme, P. A., Happonen, I., Sukura, A. \& Hänninen, M.-L. (1998). Isolation and identification of Helicobacter spp. from canine and feline gastric mucosa. Appl Environ Microbiol 64, 3998-4006.

Jalava, K., On, S., Harrington, C. S., Andersen, L., Hänninen, M.-L. \& Vandamme, P. (2001). A cultured strain of "Helicobacter heilmannii," a human gastric pathogen, identified as H. bizzozeronii: evidence for zoonotic potential of Helicobacter. Emerg Infect Dis 7, 1036-1038.

Kirkbride, C. A., Gates, C. E. \& Collins, J. E. (1986). Abortion in sheep caused by a nonclassified, anaerobic, flagellated bacterium. Am J Vet Res 47, 259-262.

Kostia, S., Veijalainen, P., Hirvi, U. \& Hänninen, M.-L. (2003). Cytolethal distending toxin B gene $(c d t B)$ homologues in taxa 2, 3 and 8 and in six canine isolates of Helicobacter sp. flexispira. J Med Microbiol 52, 103-108.

Lee, A., Phillips, M. W. O'Rourke, J. L. \& 7 other authors (1992). Helicobacter muridarum sp. nov., a microaerophilic helical bacterium with a novel ultrastructure isolated from the intestinal mucosa of rodents. Int J Syst Bacteriol 42, 27-36.

Linton, D., Clewley, J. P., Burnens, A., Owen, R. J. \& Stanley, J. (1994). An intervening sequence (IVS) in the 16S rRNA gene of the eubacterium Helicobacter canis. Nucleic Acids Res 22, 1954-1958.

Ljungh, Å. \& Wadström, T. (2002). The role of microorganisms in biliary tract disease. Curr Gastroenterol Rep 4, 167-171.

Matsukura, N., Yokomuro, S., Yamada, S., Tajiri, T., Sundo, T., Hadama, T., Kamiya, S., Naito, Z. \& Fox, J. G. (2002). Association between Helicobacter bilis in bile and biliary tract malignancies: H. zbilis in bile from Japanese and Thai patients with benign and malignant diseases in the biliary tract. Jpn J Cancer Res 93, 842-847.

Mendes, E. N., Queiroz, D. M., Dewhirst, F. E., Paster, B. J., Moura, S. B. \& Fox, J. G. (1996). Helicobacter trogontum sp. nov., isolated from the rat intestine. Int J Syst Bacteriol 46, 916-921. 
Mikkonen, T., Kärenlampi, R. \& Hänninen, M.-L. (2004). Phylogenetic analysis of gastric and enterohepatic Helicobacter species based on partial HSP60 gene sequences. Int J Syst Evol Microbiol 54, 753-758.

Nilsson, l., Kornilovs'ka, l., Lindgren, S., Ljungh, Å. \& Wadström, T. (2003). Increased prevalence of seropositivity for non-gastric Helicobacter species in patients with autoimmune liver disease. J Med Microbiol 52, 949-953.

Paster, B. J., Lee, A., Fox, J. G., Dewhirst, F. E., Tordoff, L. A., Fraser, G. J., O'Rourke, J. L., Taylor, N. S. \& Ferrero, R. (1991). Phylogeny of Helicobacter felis sp. nov., Helicobacter mustelae, and related bacteria. Int J Syst Bacteriol 41, 31-38.

Patterson, M. M., Schrenzel, M. D., Feng, Y., Xu, S., Dewhirst, F. E., Paster, B. J., Thibodeau, S. A., Versalovic, J. \& Fox, J. G. (2000). Helicobacter aurati sp. nov., a urease-positive Helicobacter species cultured from gastrointestinal tissues of Syrian hamsters. J Clin Microbiol 38, 3722-3728.

Robertson, B. R., O'Rourke, J. L., Vandamme, P., On, S. L. \& Lee, A. (2001). Helicobacter ganmani sp. nov., a urease-negative anaerobe isolated from the intestines of laboratory mice. Int J Syst Evol Microbiol 51, 1881-1889.

Romero, S., Archer, J. R., Hamacher, M. E., Bologna, S. M. \& Schell, R. F. (1988). Case report of an unclassified microaerophilic bacterium associated with gastroenteritis. J Clin Microbiol 26, 142-143.

Saunders, K. E., Shen, Z., Dewhirst, F. E., Paster, B. J., Dangler, C. A. \& Fox, J. G. (1999). Novel intestinal Helicobacter species isolated from cotton-top tamarins (Saguinus oedipus) with chronic colitis. J Clin Microbiol 37, 146-151.

Shen, Z., Fox, J. G., Dewhirst, F. E., Paster, B. J., Foltz, C. J., Yan, L., Shames, B. \& Perry, L. (1997). Helicobacter rodentium sp. nov., a urease-negative Helicobacter species isolated from laboratory mice. Int J Syst Bacteriol 47, 627-634.

Silva, C. P., Pereira-Lima, J. C., Oliveira, A. G., Guerra, J. B., Marques, D. J., Sarmanho, L., Cabral, M. M. D. Á. \& Queiroz,
D. M. M. (2003). Association of the presence of Helicobacter in gallbladder tissue with cholelithiasis and cholecystitis. J Clin Microbiol 41, 5615-5618.

Solnick, J. V. \& Schauer, D. B. (2001). Emergence of diverse Helicobacter species in the pathogenesis of gastric and enterohepatic diseases. Clin Microbiol Rev 14, 59-97.

Sorlin, P., Vandamme, P., Nortier, J., Hoste, B., Rossi, C., Pavlof, S. \& Struelens, M. J. (1999). Recurrent "Flexispira rappini" bacteremia in an adult patient undergoing hemodialysis: case report. J Clin Microbiol 37, 1319-1323.

Stackebrandt, E., Frederiksen, W., Garrity, G. M. \& 10 other authors (2002). Report of the ad hoc committee for the re-evaluation of the species definition in bacteriology. Int $J$ Syst Evol Microbiol 52, 1043-1047.

Stanley, J., Linton, D., Burnens, A. P., Dewhirst, F. E., On, S. L., Porter, A., Owen, R. J. \& Costas, M. (1994). Helicobacter pullorum sp. nov. - genotype and phenotype of a new species isolated from poultry and from human patients with gastroenteritis. Microbiology 140, 3441-3449.

Tee, W., Leder, K., Karroum, E. \& Dyall-Smith, M. (1998). “Flexispira rappini” bacteremia in a child with pneumonia. J Clin Microbiol 36, 1679-1682.

Vandamme, P., Pot, B., Gillis, M., de Vos, P., Kersters, K. \& Swings, J. (1996). Polyphasic taxonomy, a consensus approach to bacterial systematics. Microbiol Rev 60, 407-438.

Vandamme, P., Harrington, C. S., Jalava, K. \& On, S. L. (2000). Misidentifying helicobacters: the Helicobacter cinaedi example. J Clin Microbiol 38, 2261-2266.

Weir, S., Cuccherini, B., Whitney, A. M. \& 9 other authors (1999). Recurrent bacteremia caused by a "Flexispira"-like organism in a patient with X-linked (Bruton's) agammaglobulinemia. J Clin Microbiol 37, 2439-2445. 